\title{
Pengaruh Kepercayaan, Pengetahuan dan Sikap Terhadap Akses Jamban Di Perkotaan
}

\author{
Mila Mardotillah ${ }^{1}$, Budhi Gunawan ${ }^{2}$, Rini S. Soemarwoto ${ }^{3}$, Ardini S. Raksanagara ${ }^{4}$ \\ Faculty of Social and Political Science, Universitas Padjadjaran, Bandung. Email: jayasuwirta@gmail.com¹, \\ budhi.gunawan@unpad.ac.id ${ }^{2}$,rinisoemarwoto@gmail.com ${ }^{3}$, araksanagara@yahoo.com ${ }^{4}$
}

\author{
Diterima: 04/12/2018 \\ Direview: 04/12/2018 \\ Diterbitkan: 30/12/2019
}

Hak Cipta @ 2019 oleh Penulis (dkk) dan Jurnal Sosial Humaniora (JSH)

*This work is licensed under the Creative

Commons Attribution International License (CC BY 4.0).

http://creativecommons.org/licenses/by/4.0/ cc) (i) Open Access

\section{Subject Area : Social and Politics (Sosial dan Politik)}

\section{Abstract [in ENGLISH]}

The difficult access of urban healthy latrines is influenced by population density, limitation of infrastructure and high mobility. Cultural factors become one of the keys in influencing people behavior to access healthy latrines. The aim this research was to explore the cultural factors influencing the people to access the healthy latrine. The method used was a retrospective quantitative approach with cross sectional analytical method (cross sectional) in order to know the cultural factors that influence people behaviour in using healthy latrines. The research found that the cultural factors related to access of healthy latrines include belief on the taboo, gender, beliefs and differences of each generation. The significant influential factors are trust, knowledge and attitude. While other factors simultaneously affect the citizen in behaving toward using healthy latrines. The conclusion was that the behaviour in accessing healthy latrines is created by individual's knowledge, attitudes and actions. The behaviour will be established and successful if the cultural factor approach is carried out simultaneously. The individual's concept about something is the impact of the individual's way of thinking about something based on the culture containing non-individual but public meaning. So, when the system of meaning belongs to the collective society, society can have the same pattern of behaviour. The cultural factors can serve as a basis for improving urban residents' access to healthy latrines.

Keywords: Cultural factor; access to latrines; urban areas

\section{Pendahuluan}

Kesehatan lingkungan merupakan isu global dalam Program Internasional Sustainable Development Goals (SDG's) sejak tahun 2015 yang tertuang dalam pilar ke 6 yaitu Program Air Bersih dan Sanitasi. Sanitasi yang dimaksud mencakup kepada jamban, septiktank, pengolahan limbah cair dan pengelolaan sampah di masyarakat. Sanitasi merupakan sebuah proses untuk memelihara tempat agar bersih dan higienis terutama ketersediaan air bersih, sistem limbah baik padat maupun cair (van Vliet, 2010). Dalam pemeliharaannya, penduduk dan pemerintah bertanggung jawab untuk memenuhi sanitasi sesuai dengan kemampuan.

Data menyatakan terdapat lebih dari 2,5 miliar penduduk di dunia hidup tanpa memiliki akses jamban sehat, air bersih dan sarana pembuangan (USAID, 2016). Kesulitan air bersih dan sanitasi terjadi pada 663 juta orang di seluruh dunia yang berdampak pada peningkatan kejadian penyakit menular (WSP, 2015). Sanitasi yang tidak memadai, praktek kebersihan yang buruk, kepadatan penduduk yang berlebihan, peningkatan kebutuhan air bersih dan air yang terkontaminasi secara sekaligus dapat menciptakan kondisi 
yang tidak sehat terutama di daerah-daerah kumuh perkotaan (UNICEF, 2012). Kekurangan air bersih akibat pencemaran tinja menjadi masalah kesehatan dan berpengaruh kepada angka kesakitan penyakit yang disebabkan oleh water borne disease misalnya rotavirus yang terdapat dalam tinja manusia dan menginfeksi melalui sumber air (Singer, 2015). Hal tersebut akan berdampak buruk pada status kesehatan penduduk.

Lingkungan, baik ditinjau dari fisik, budaya dan faktor sosial menjadi mediasi pada kejadian angka penyakit infeksi (Singer, 2015). Penurunan daya dukung lingkungan akibat air tercemar menimbulkan penyakit berbasis lingkungan seperti disentri, kolera, tipus, hepatitis, leptospirosis, malaria, demam berdarah, kudis, penyakit pernapasan kronis dan infeksi parasit usus (UNICEF, 2012). Faktor lingkungan dan perilaku merupakan faktor yang saling terkait dan mempunyai peranan lebih besar dalam memengaruhi derajat kesehatan dalam kaitannya dengan akses sanitasi.

Perhatian sanitasi selama ini cenderung kepada teknis, akan tetapi mengabaikan sisi ekologi, sosial, ekonomi dan budaya. Faktor teknis meliputi ketersediaan fasilitas sanitasi tiap rumah tangga dan penyediaan sarana di masyarakat membutuhkan pengelolaan yang tepat dan teknologi yang memadai terutama di kotakota besar baik dari segi kualitas maupun kuantitas (van Vliet, 2010; Jewit, 2011). Peningkatan jumlah penduduk dan pola kebiasaan setiap daerah menyebabkan sanitasi tidak cukup diselesaikan dengan pendekatan teknologi, tetapi membutuhkan pendekatan ekologi, sosial dan budaya. Sanitasi melalui pendekatan sosial yang melibatkan penyedia, teknisi dan perilaku pengguna merupakan pendekatan efektif dalam merubah perilaku sanitasi ke arah yang lebih baik (van Vliet 2010). Pendekatan sanitasi dari sisi sosial merupakan langkah dalam meningkatkan sanitasi itu sendiri. Perkotaan sebagai daerah urban membutuhkan sanitasi yang layak. Pendekatan sanitasi dari sudut pandang ekologi, sosial dan budaya terutama di perkotaan selama ini belum banyak di lakukan. Bagi Negara-negara berkembang, kebutuhan sanitasi perkotaan meningkat bukan hanya pada penyediaan sarana tetapi membutuhkan keberlanjutan secara mandiri. Sanitasi perkotaan dalam pendekatan sosial merupakan suatu proses untuk meyakinkan masyarakat dan individu untuk berinvestasi dan membuat perubahan perilaku mandiri merupakan dasar terwujudnya keberlanjutan sanitasi termasuk dalam pemeliharaan sarananya (IUWASH, 2015). Peran tokoh masyarakat setempat tidak terlepas dari keberlanjutan sanitasi sebagai pemersatu dari beragamnya masyarakat.

Pendekatan budaya dalam penggunaan jamban, telah digunakan dalam penelitian mengenai keterbatasan jamban sehat di India pada saat terjadinya kontaminasi makanan dan air akibat tinja manusia. Hasil penelitian menemukan bahwa penyebabnya adalah masyarakat membuang tinja di tempat terbuka dan tinja menjadi perindukan lalat. Pendekatan pembuatan jamban disesuaikan dengan kondisi dan kemampuan masyarakat mengadaptasi disesuaikan dengan kondisi tanah, iklim dan ketersediaan air. Penelitian lainnya pada tahun 1950, pemerintah Amerika membangun WC di daerah gurun yang kemudian WC tersebut menjadi perindukan lalat dan menyebarkan penyakit. Sebelumnya masyarakat memakai jamban cara kering karena tinja di alam terbuka gurun lebih cepat kering sehingga lalat tidak berkembang biak. Intervensi jamban memperlihatkan bagaimana perilaku buang air dipengaruhi oleh budaya setempat (Foster, 2006).

Kota Bandung sebagai Ibu Kota Provinsi Jawa Barat memiliki jumlah penduduk perkotaan tertinggi di Jawa Barat yaitu sebesar 2.394.873 orang (Badan Pusat Statistik Provinsi Jawa Barat dan Bappeda Provinsi Jawa Barat, 2012). Perkembangan Kota Bandung menjadikan budaya baru Indonesia yaitu sebuah budaya 
urban pada umumnya yang memerlukan akses sanitasi bagi warganya. Kota Bandung dapat dijadikan contoh bagi daerah lain terutama bila hal positif dalam penggunaan jamban sehat perkotaan.

Akses sanitasi Kota Bandung sebesar 1-2 \% (WSP, 2015). Kasus diare di Kota Bandung pada tahun 2015 melebih target sasaran yaitu 107,7\% yang berarti terdapat 57.425 kasus dari target kasus 53.299 untuk semua golongan umur (Profil Dinas Kesehatan, 2015). Kota Bandung menempati urutan ke 8 dari 9 kota-kota di Jawa Barat dalam pencapaian perilaku sanitasi berdasarkan akses jamban sehat yaitu sebesar 58,47 \%, sedangkan capaian kelurahan yang telah melaksanakan Sanitasi Total Berbasis Masyarakat di Kota Bandung baru mencapai 21,9\%, yang berarti 33 kelurahan dari 151 kelurahan telah melaksanakan pemicuan Sanitasi Total Berbasis Masyarakat (Profil Dinas Kesehatan, 2015).

Sampai dengan periode Triwulan III tahun 2017, dari 33 kelurahan di Kota Bandung, terdapat 1 kelurahan yaitu Kelurahan Rancanumpang yang telah diberikan pemicuan dan diverifikasi menunjukkan hasil bahwa seluruh masyarakatnya sudah tidak buang air sembarangan, memiliki akses jamban sehat dan dinyatakan sebagai kelurahan Open Defecation Free (ODF) yang berarti $100 \%$ masyarakat sudah berperilaku saniter dalam buang air.

Pendekatan sanitasi melalui konsep emik dan etik ilmu Antropologi dan Epidemiologi masih jarang dilakukan. Selain itu, beberapa penelitian bidang Antropologi Kesehatan masih terfokus di perdesaan dan memotret sulitnya penerapan sanitasi. Penelitian ini lebih memfokuskan bagaimana masyarakat perkotaan dapat berhasil mewujudkan akses jamban dengan análisis Epidemiologi dan Antropologi.

Dalam keberhasilan ini, faktor-faktor budaya apa saja yang mempengaruhi keberhasilan Kelurahan Rancanumpang mewujudkan akses $100 \%$ terhadap jamban sehat.

\section{Metode Penelitian}

Metode yang digunakan adalalah penelitian kuantitatif dengan memakai metode retrospektif potong lintang analitik (cross sectional) yang berarti bahwa data diambil pada saat waktu tertentu secara langsung, dilakukan untuk mengetahui hubungan antara faktor predisposisi terhadap perilaku penggunaan jamban (Lapau \&Syaifuddin, 2015). Analisis kuantitatif yang dilakukan adalah melihat hubungan predisposisi terhadap perilaku buang air memakai metode regresi linier berganda. Dalam pendekatan kuantitatif ini digunakan uji statistik yaitu uji regresi yang bertujuan untuk mengetahui pengaruh variabel bebas $(\mathrm{X})$ terhadap variabel terikat (Y). Paradigma penelitian terdapat dalam gambar 3.1 :

Gambar 1. Paradigma penelitian

\section{$€$}

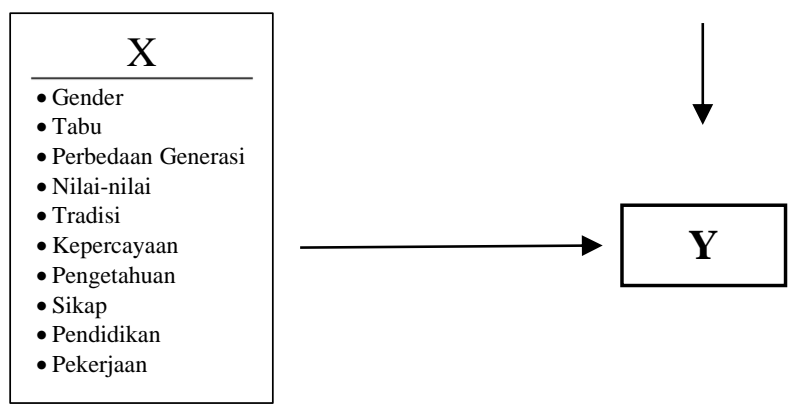


Keterangan :

$\mathrm{X} \quad$ : Faktor Predisposisi/Variabel Terikat

Y : Perilaku/Variabel Bebas

Dari diagram tersebut, dapat diartikan hubungan antara X merupakan hubungan kausal dimana variabel yang satu dengan yang lainnya mempunyai kaitan korelatif mempengaruhi Y. Sedangkan $€$ merupakan unsur atau variabel lain yang berpengaruh terhadap Y tetapi dalam penelitian ini diabaikan nilainya.

Dalam menguji instrumen kuesioner penelitian, dilakukan dengan cara uji antara lain:

\section{Uji Validitas}

Sebelum data diproses terlebih dahulu dilakukan uji validitas untuk menguji alat ukur atau kuesioner. Validitas menunjukkan sejauhmana suatu alat pengukur itu mengukur apakah sesuai dengan standar yang ditetapkan atau mengukur apakah sesuai dengan yang diukur (Ancok, 1989). Untuk mengukur validitas kuesioner dilakukan dengan metode korelasi pearson product moment, yaitu hasil dari seluruh kuesioner yang berupa skor dikorelasikan (Nazir, 2005). Valid tidaknya alat ukur tersebut dapat diuji dari penjumlahan semua skor pertanyaan. Apabila korelasi antara skor total masing-masing pertanyaan signifikan, maka dapat dikatakan bahwa alat pengukur tersebut valid karena memiliki nilai lebih dari 0,7.

\section{Uji Keandalan Alat Ukur atau Reliabilitas}

Alat ukur yang digunakan dalam penelitian ini adalah kuesioner tertutup. Keterandalan suatu alat ukur berarti kemampuan alat ukur tersebut untuk mengukur gejala secara konsisten. Alat pengukur data tetap menunjukkan hasil ukuran yang sama, walaupun digunakan oleh orang yang sama di tempat yang berbeda, atau orang yang lain pada tempat yang sama.

Untuk mengukur tingkat keandalan alat ukur secara interval, digunakan nilai alpha cronbach. Nilai alpha cronbach dapat dihitung dengan menggunakan rumus sebagai berikut :

$$
\alpha=\frac{k r}{1+(k-1) r}
$$

Keterangan : $\quad \alpha=$ nilai keandalan

$$
\begin{aligned}
& \mathrm{r}=\text { rata-rata korelasi antar variabel } \\
& \mathrm{k}=\text { jumlah variabel }
\end{aligned}
$$

Menetapkan besarnya $\alpha$ untuk menentukan suatu alat ukur dinilai andal atau tidak, dalam literatur atau buku penelitian tidak memiliki standar yang baku. Dalam penelitian ini digunakan acuan $\alpha>=0.5$ sebagai kriteria alat ukur yang digunakan adalah baik (andal). Perhitungan keandalan alat ukur digunakan dengan menggunakan alat bantu program Statistical Package for Social Science (SPSS).

Dalam uji reliabilitas, reliabilitas sempurna bila memiliki nilai $\alpha>90$, hasil menunjukkan bahwa dari 54 pertanyaan yang diujikan, mendapatkan nilai 0.96 yang berarti memilki reliabilitas sempurna.

Setelah pengujian instrumen, kemudian dilakukan teknik pengumpulan data dengan langkah-langkah :

1) Pembuatan kuesioner dan data set berdasarkan tinjauan pustaka yang telah di buat. 
2) Ethical Clearence dari Komisi Etik Universitas Padjadjaran

3) Ijin penelitian dari Badan Kesatuan Bangsa, Perlindungan dan Pemberdayaan Masyarakat (BKPPM) Kota Bandung.

4) Membuat konsep penelitian berdasarkan wawancara dan membuat formulir pengisian data berupa checklist memuat variabel-variabel yang akan diteliti.

Selanjutnya, setelah penentuan responden, maka penelitian kuantitatif dilakukan dengan kegiatan :

1) Pengambilan data : menyebarkan kuesioner dan inspeksi sanitasi terhadap jamban juga wawancara informan.

2) Wawancara awal dengan pegawai Dinas Tata Ruang Cipta Karya Kota Bandung, pegawai Dinas Kesehatan Kota Bandung, Petugas Kesehatan Lingkungan Puskesmas, Camat dan Lurah setempat serta Tokoh Masyarakat

3) Pengumpulan dilakukan dengan menyalin variabel yang dibutuhkan dengan memakai formulir pengisian manual/lembar check list sambil dilakukan editing.

4) Pemberian kode untuk variabel-variabel yang dibutuhkan.

5) Formulir yang telah diisi ditabulasi dan diolah dengan menggunakan program komputer.

6) Pengolahan data

Penelitian dilakukan pada bulan September 2017 sampai Januari 2018. Subjek penelitian adalah keluarga dengan unit analisis individu yang terdaftar dalam Kartu Keluarga Kelurahan Rancanumpang. Dalam penelitian ini akan diteliti mengenai perilaku individu dalam keluarga dalam penggunaan jamban terdiri dari pengetahuan, sikap dan praktek masyarakat terhadap jamban mengacu pada faktor predisposisi. Data yang diambil dari wawancara pada individu dewasa yang merupakan bagian dari KK yang dapat menggambarkan pola perilaku keluarga dalam penggunaan jamban sehat. Hasil tersebut dapat mewakili seluruh keluarga yang tercatat dalam KK.

Sarana termasuk jumlah dan kondisi sarana fisik jamban, air bersih yang dipakai dan air buangan hasil pengolahan yang dialirkan ke sungai atau badan air dan kualitas air bersih KK tersebut menjadi data tambahan yang diambil tercakup pada faktor penguat dan faktor pendorong. Penetapan sampling memakai teknik secara proporsional random sampling yaitu pengambilan sampel dengan memperhatikan pertimbangan unsur-unsur atau kategori dalam populasi penelitian.

Populasi dihitung dari data KK Kelurahan Rancanumpang sebanyak 1162 KK. Sampel yang akan diambil sebanyak $285 \mathrm{KK}$.

\section{Hasil Penelitian dan Pembahasan}

\section{Gambaran Umum}

Kelurahan Rancanumpang termasuk ke dalam wilayah Kecamatan Gedebage Kota Bandung, berdasarkan Peraturan Daerah Pemerintah Kota Bandung Nomor 06 Tahun 2006 Tentang Pemekaran Wilayah Kecamatan dan Kelurahan Di Lingkungan Pemerintah Kota Bandung.

Percepatan peningkatan akses sanitasi sejak tahun 2005 melalui pendekatan Community-Led Total Sanitation (CLTS). Tahun 2009, diperkuat dengan memasukkan pada Rencana Pembangunan Jangka 
Menengah Nasional (RPJMN 2010 - 2014) sejalan dengan komitmen pemerintah dalam pencapaian target MDG's 2015. Selanjutnya Sanitasi Total Berbasis Masyarakat (STBM) dimulai pada Tahun 2008 berdasarkan Keputusan Menteri Kesehatan No. 852/SK/Menkes/SK/IX/2008 dan terakhir Peraturan Menteri Kesehatan No. 3 Tahun 2014 tentang STBM. Pemicuan dilakukan bertahap pada seluruh Kelurahan Wilayah Kota Bandung.

Kelurahan Rancanumpang dikelilingi oleh persawahan. Sekitar $40 \%$ warga melakukan buang air di sawah, kebun atau kali. Perubahan secara perlahan dimulai pada tahun 2010 dipelopori oleh Ketua RW 01 dan diikuti oleh RW lainnya. Pemicuan yang dilakukan adalah pilar 1 yaitu Stop Buang Air Besar Sembarangan (STOP BABS) terutama pada RW 01 dan 02 yang pada saat dilakukan pemicuan masih terdapat penduduk yang tidak memiliki akses terhadap jamban. Masyarakat bekerjasama dengan LPM dan Kelurahan agar semua warga dapat memiliki akses terhadap jamban dan air bersih.

Kondisi perilaku buang air besar penduduk di Kelurahan Rancanumpang terutama penduduk RW 01 dan RW 02 sejak tahun 2010 sampai tahun 2014 adalah ke kali, sawah dan kebun. Salah satu penggerak warga agar mulai mengakses jamban adalah Ketua RW 01 dan RW 02 dengan mempromosikan pentingnya buang air besar di jamban. Sarana jamban Kelurahan Rancanumpang meningkat sejak tahun 2014, seperti dalam Bagain 1:

Bagan 1. Perkembangan Akses Jamban di Kelurahan Rancanumpang Tahun 2010-2017

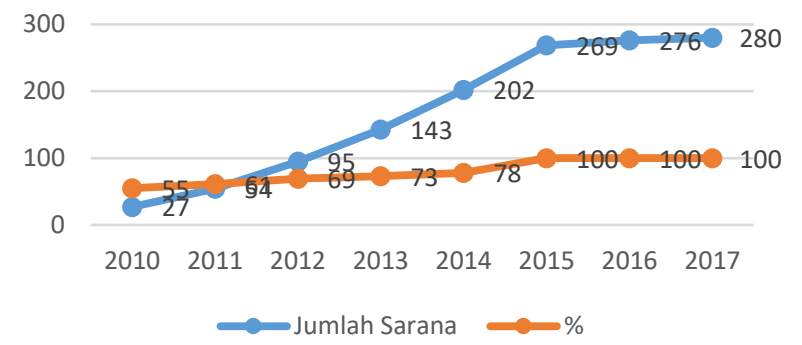

Kenaikan jumlah sarana jamban dan septiktank seiring meningkatnya kesadaran masyarakat akan pentingnya jamban Pemicuan dari pemerintah menghasilkan komitmen dari aparat dan masyarakat untuk meningkatkan akses jamban, sehingga pada tanggal 25 November 2015, penduduk mendeklarasikan bahwa seluruh masyarakat sudah $100 \%$ mengakses jamban sehat.

\section{Hasil penelitian}

Bandung merupakan ibu kota provinsi dan memiliki gaya hidup modern sebagai kota urban. Perkembangan kota Bandung menjadikan budaya baru Indonesia yaitu sebuah budaya urban pada umumnya (van Klinken \& Berenschot, 2014). Masyarakat dalam memandang jamban tidak hanya sebagai sarana yang harus ada dan harus terpenuhi, tetapi ada makna tertentu terkait fungsi dan bahan buangan jamban. Beberapa sudut pandang responden terkait jamban :

1. Gender

Pandangan konstruksi sosial, hubungan sosial dan partisipasi diantara perempuan dan laki-laki baik di ruang publik maupun pribadi responden. Pandangan masyarakat di Kelurahan Rancanumpang terhadap 
gender mencapai paling tinggi $96,5 \%$ sangat setuju apabila setiap orang tanpa memandang gender bertanggung jawab terhadap ketersediaan jamban.

2) Tabu

Tabu merupakan larangan yang diturunkan secara turun temurun dan menjadi kepercayaan suatu masyarakat, dapat menjadi pedoman di masyarakat. Pandangan masyarakat terhadap tabu mencapai paling tinggi 94,5\% sangat setuju bahwa jamban harus bersih dan tinja bersifat negatif/najis.

3) Perbedaan Generasi

Perbedaan Generasi merupakan perbedaan tingkatan usia yang menentukan perencanaan dan cara dalam mewujudkan jamban sehat di keluarga. Pandangan masyarakat terhadap perbedaan generasi mencapai paling tinggi 93,7\% sangat setuju bahwa generasi muda sebagai agen perubahan terhadap perilaku penggunaan jamban.

4) Nilai-nilai

Nilai-nilai merupakan suatu hal yang dianggap baik atau buruk dan menjadi pedoman bagi kehidupan masyarakat. Nilai mengarah kepada manfaat yang diterima oleh masyarakat. Pandangan masyarakat terhadap nilai-nilai mencapai paling tinggi $89,5 \%$ setuju bahwa menggunakan jamban merupakan bagian dari pelaksanaan adab.

5) Tradisi

Tradisi merupakan praktik yang telah dilakukan sejak lama dan menjadi bagian dari kehidupan suatu kelompok masyarakat. Pandangan tradisi terhadap tradisi mencapai paling tinggi 95,8 \% sangat setuju bahwa pengelolaan tinja harus memperhatikan lingkungan sekitar.

6) Kepercayaan

Kepercayaan merupakan cerminan keyakinan individu yang berkembang di masyarakat. Pertanyaan terkait kepercayaan mencapai paling tinggi $93 \%$ sangat setuju bahwa menggunakan jamban merupakan salah satu ketaatan terhadap agama.

7) Pengetahuan

Pengetahuan merupakan hasil dari tahu yang dilakukan oleh indera terhadap objek tertentu. Pertanyaan terkait pengetahuan mencapai paling tinggi $89,8 \%$ setuju bahwa pengetahuan mendukung terhadap pelaksanaan penggunaan jamban.

8) Sikap

Sikap terbentuk setelah pengetahuan dimiliki oleh individu. Sikap terbentuk dengan menerima, menanggapi, menghargai dan bertanggung jawab. Pandangan terhadap sikap masyarakat terkait jamban mencapai paling tinggi 91,2\% sangat setuju bahwa keberadaan jamban harus sesuai ketentuan yang disepakati bersama.

9) Pendidikan

Pandangan Masyarakat terhadap kaitan pendidikan mencapai paling tinggi 98,2 \% sangat setuju bahwa pendidikan menunjang kepada perilaku masyarakat menggunakan jamban.

10) Pekerjaan 
Pekerjaan merupakan aktifitas pekerja bertujuan menerima upah atau bentuk penggajian dalam bentuk apapun (ILO, 2011). Pandangan Masyarakat terhadap kaitan pendidikan terhadap tabu mencapai paling tinggi 95,8 \% setuju bahwa pekerjaan apapun mendukung kepada ketersediaan dan pemakaian jamban yang memenuhi syarat kesehatan.

11) Perilaku stop buang air sembarangan

Perilaku merupakan gabungan dari pengetahuan, sikap dan tindakan. Tindakan merupakan hasil dari pengetahuan dan sikap yang telah dimiliki oleh masyarakat. Pandangan Masyarakat yang menjadikan hasil tindakan dan menjadikan perilaku penggunaan jamban mencapai paling tinggi 89,8\% setuju bahwa pemberian pengetahuan dan pembinaan kepada masyarakat merupakan hal penting dalam akses jamban.

Keseluruhan faktor-faktor tersebut menjadi faktor yang berada dalam pikiran individu dan sangat dipengaruhi oleh kecenderungan untuk menerima atau menolak sesuatu berdasarkan pengalaman dan norma yang dimilikinya. Beberapa variabel dalam penelitian ini menunjukan arah positif dan negatif terhadap perilaku penggunaan jamban sehat seperti dalam tabel 1.

Tabel 1. Hasil Perhitungan Faktor Predisposisi Penggunaan Jamban Sehat Keluarga Responden Kelurahan Rancanumpang

\begin{tabular}{|c|c|c|c|c|c|c|c|}
\hline \multirow[b]{2}{*}{ Model } & \multicolumn{2}{|c|}{$\begin{array}{c}\text { Unstandardized } \\
\text { Coefficients }\end{array}$} & \multirow[t]{2}{*}{$\begin{array}{l}\text { Standa } \\
\text { rdized } \\
\text { Coeffi } \\
\text { cients } \\
\end{array}$} & \multirow[t]{2}{*}{$\mathrm{t}$} & \multirow[t]{2}{*}{ Sig. } & \multicolumn{2}{|c|}{$\begin{array}{l}95.0 \% \text { Confidence } \\
\text { Interval for B }\end{array}$} \\
\hline & & $\begin{array}{c}\text { Std. } \\
\text { Error }\end{array}$ & & & & $\begin{array}{l}\text { Lower } \\
\text { Bound }\end{array}$ & $\begin{array}{l}\text { Upper } \\
\text { Bound } \\
\end{array}$ \\
\hline (Constant) & 24.411 & 6.086 & & 4.011 & .000 & 12.430 & 36.391 \\
\hline MSIXGender & .022 & .047 & .037 & .478 & .633 & -.069 & .114 \\
\hline MSIXTabu & .018 & .025 & .046 & .726 & .469 & -.031 & .067 \\
\hline MSIXPerbedaan Generasi & -.403 & .330 & -.082 & -1.222 & .223 & -1.053 & .246 \\
\hline MSIXNilai-nilai & .036 & .323 & .008 & .113 & .910 & -.600 & .673 \\
\hline MSIXTradisi & -.167 & .080 & -.138 & -2.072 & .809 & -.325 & -.008 \\
\hline MSIXKepercayaan & .232 & .078 & .212 & 2.995 & .003 & .080 & .385 \\
\hline MSIXPengetahuan & .020 & .081 & .014 & .242 & .039 & -.139 & .178 \\
\hline MSIXSikap & .151 & .053 & .184 & 2.844 & .005 & .047 & .256 \\
\hline MSIXPendidikan & -.061 & .157 & -.025 & -.390 & 697 & -.369 & .247 \\
\hline MSIXPekerjaan & .066 & .083 & .048 & .795 & .427 & -.097 & .229 \\
\hline
\end{tabular}

Pada tabel 1 seluruh data dari faktor predisposisi memiliki varian yang sama/homogen. Faktor predisposisi ini merupakan faktor prediktor atau faktor yang dapat diperkirakan memengaruhi terhadap perilaku jamban. Dari 10 faktor predisposisi terdapat hasil beragam dan hanya 3 yang memiliki hasil siginifikan antara lain:

1) Kepercayaan : faktor kepercayaan mempunyai hasil koefisien B positif yang berarti kepercayaan merupakan faktor utama dalam peningkatan perilaku penggunaan jamban sehat. Selain itu, berpengaruh secara signifikan terhadap perilaku penggunaan jamban sehat. Hal ini dimungkinkan bahwa kepercayaan penduduk terhadap keyakinan agama dan meyakini bahwa kebersihan yang terwujud dalam penyediaan jamban sehat merupakan bukti ketaatan.

2) Pengetahuan : pengetahuan mempunyai hasil koefisien B positif yang berarti bahwa pengetahuan merupakan faktor utama dalam peningkatan perilaku penggunaan jamban sehat. Selain itu, berpengaruh secara signifikan terhadap perilaku penggunaan jamban sehat. Hal ini dimungkinkan bahwa pengetahuan adalah hal mendasar dalam pembentukan perilaku. 
3) Sikap : Sikap mempunyai hasil koefisien B positif yang berarti bahwa Sikap merupakan faktor utama dalam peningkatan perilaku penggunaan jamban sehat. Selain itu, berpengaruh secara signifikan terhadap perilaku penggunaan jamban sehat. Hal ini telah sesuai bahwa sikap bila digabungkan dengan pengetahuan akan menghasilkan tindakan yang dapat membentuk perilaku penggunaan jamban sehat.

Secara keseluruhan, faktor-faktor predisposisi responden dalam membentuk perilaku penggunaan jamban sehat terdapat dalam tabel 2.

Tabel 2. Hasil Perhitungan Anova Keluarga Responden terhadap Faktor Predisposisi Perilaku Menggunakan Jamban Sehat Kelurahan Rancanumpang

\begin{tabular}{|c|c|c|c|c|c|}
\hline Model & $\begin{array}{l}\text { Sum of } \\
\text { Squares }\end{array}$ & df & $\begin{array}{l}\text { Mean } \\
\text { Square }\end{array}$ & $\mathrm{F}$ & Sig. \\
\hline Regression & 77.511 & 10 & 7.751 & 2.317 & $.012^{\mathrm{b}}$ \\
\hline Residual & 916.574 & 274 & 3.345 & & \\
\hline Total & 994.085 & 284 & & & \\
\hline $\begin{array}{l}\text { a. Depender } \\
\text { b. Predictor } \\
\text { MSIX2, MS }\end{array}$ & $\begin{array}{l}\text { ble: MSIY } \\
\text { stant), M } \\
\text { SIX6, MS }\end{array}$ & $\begin{array}{l}0, \text { MS } \\
\text { MSIX }\end{array}$ & 9, MSIX5, & IX4, & SIX7, \\
\hline
\end{tabular}

Dalam perhitungan keseluruhan faktor predisposisi terhadap perilaku menggunakan jamban sehat didapatkan hasil 0.012 yang berarti signifikan. Faktor predisposisi dilihat dari masing-masing variable terikatnya berpengaruh kepada perilaku penggunaan jamban sehat.

Pengujian dilakukan terhadap pengaruh faktor-faktor predisposisi budaya terkait penggunaan jamban sehat responden Kelurahan Rancanumpang, semua faktor predisposisi di diuji dan digabungkan untuk melaihat pengaruhnya. Pengaruh total terdapat dalam tabel 3.

Tabel 3 Hasil Perhitungan Anova Keluarga Responden terhadap Penilaian Multivariat Faktor Predisposisi Perilaku Menggunakan Jamban Sehat Kelurahan Rancanumpang

\begin{tabular}{lrrrrr}
\hline Model & Sum of Squares & df & Mean Square & F & Sig. \\
\hline Regression & 20.124 & 1 & 20.124 & 5.847 & $.016^{\mathrm{b}}$ \\
Residual & 973.960 & 283 & 3.442 & & \\
Total & 994.085 & 284 & & & \\
a. Dependent Variable: MSIY & & & \\
b. Predictors: (Constant), TotMSIX \\
\hline \multicolumn{5}{c}{ Sumber : Hasil penghitungan statistik penelitian, 2017 }
\end{tabular}

Dalam perhitungan pengatuh total dari faktor predisposisi penggunaan jamban sehat, didapat hasil 0.016 yang berarti bila faktor predisposisi dilakukan bersama-sama berpengaruh kepada perilaku responden dalam menggunakan jamban sehat.

\section{Pembahasan}

Peran faktor budaya terkait penggunaan jamban oleh keluarga diperkotaan mempengaruhi bagaimana setiap keluarga memiliki kesadaran mandiri menggunakan jamban. Faktor-faktor tersebut antara lain :

1. Gender

Pandangan konstruksi sosial, hubungan sosial dan partisipasi diantara wanita dan laki-laki baik di ruang publik maupun pribadi responden. Dari hasil penelitian bahwa masyarakat membagi fungsi antara peran lakilaki dan perempuan. Laki-laki sebagai pelaksana dan pencari biaya dalam memenuhi kebutuhan jamban, 
sedangkan wanita berfungsi sebagai penggerak dan memanfaatkan sumber daya sebaik-baiknya untuk mewujudkan akses jamban.

Semua wanita setuju bahwa akses jamban sangat diperlukan oleh setiap wanita di Kelurahan Rancanumpang. Jamban dikaitkan dengan gender terutama wanita yang menyatakan bahwa jamban sehat berpengaruh pada aspek psikososial wanita (Hulland, 2015). Responden di Kelurahan Rancanumpang sebesar $70.88 \%$ adalah wanita dan sebesar $48.76 \%$ sebagai ibu rumah tangga. Peran wanita dalam mengajak masyarakat berperilaku menggunakan jamban sehat sangat besar.

Perempuan sebagai kader PKK dan sebagai ketua RW memegang peranan dalam menggerakan keluarga dan masyarakat. Perempuan secara budaya kurang dihargai, namun dengan wadah organisasi dapat berperan penting, melibatkan sebanyak mungkin dalam pengembangan kegiatan sanitasi, serta bernegosiasi dengan masyarakat lain untuk perbaikan pengetahuan kesehatan Partisipasi perempuan dan melibatkan dalam program kesehatan bermanfaat bagi berkelanjutan program

2. Tabu

Tabu merupakan larangan yang diturunkan secara turun temurun dan menjadi kepercayaan suatu masyarakat dan dapat menjadi suatu pedoman di masyarakat. Perilaku penggunaan jamban di Kelurahan Rancanumpang sebagai masyarakat perkotaan masih memaknai tabu terkait jamban. Jamban dikatakan tempat kotor dapat berbeda makna. Makna "kotor" berarti suatu masalah yang keluar dari suatu tempat, makna "polusi dan tabu" merupakan batasan berbeda dan aturan sosial termasuk batas-batas nilai-nilai dalam lingkungannya yang dimiliki oleh setiap budaya (Jewit, 2011). Masyarakat berpendapat kotor karena jamban merupakan tempat pembuangan dan bahan buangan dapat dianggap benda "kotor" sehingga sebaiknya diluar rumah atau dibagian luar rumah dekat dengan air mengalir. Namun ada pula masyarakat yang memaknai jamban adalah tempat bersih karena jamban yang dimiliki dalam kondisi bersih dan selalu dibersihkan.

\section{Perbedaan Generasi}

Perbedaan Generasi merupakan perbedaan tingkatan usia yang menentukan perencanaan dan cara dalam mewujudkan jamban sehat di keluarga. Kepala Keluarga menyediakan dan memastikan bahwa jamban selalu berfungsi dengan baik. Kerjasama suami, istri dan anggota keluarga lain yang tinggal dalam satu rumah harus dapat memastikan jamban tetap berfungsi dan digunakan/dipelihara oleh anggota keluarga termasuk didalamnya memberikan pengetahuan yang benar mengenai penggunaan jamban. Pengetahuan tersebut direproduksi oleh anggota keluarga. Anak-anak merupakan agent perubahan, karena itu pengetahuan masyarakat perlu terus ditingkatkan agar dapat diajarkan pada generasi selanjutnya (Marzali, 2007).

4. Nilai-nilai

Nilai-nilai merupakan suatu hal yang dianggap baik atau buruk dan menjadi pedoman bagi kehidupan masyarakat. Nilai mengarah kepada manfaat yang diterima oleh masyarakat. Proses dan indikator budaya dari masyarakat yang dapat dijelaskan melalui nilai-nilai budaya setempat (Pizzirani, 2014). Faktor-faktor budaya yang diakomodir pada penggunaan jamban sehat di masyarakat akan meningkatkan keberlanjutan penggunaan jamban sehat. 


\section{Tradisi}

Tradisi merupakan praktik yang telah dilakukan sejak lama dan menjadi bagian dari kehidupan suatu kelompok masyarakat. Tradisi penggunaan jamban dilakukan oleh masyarakat sesuai dengan kebiasaan yang ada sejak lama. Perilaku kesehatan untuk hidup sehat yaitu semua kegiatan atau aktivitas orang dalam rangka memelihara kesehatan, seperti tindakan terhadap penyakit menular dan tidak menular, tindakan terhadap faktor-faktor yang terkait dan atau memengaruhi kesehatan juga tindakan untuk menghindari penyakit dilakukan sebelumnya secara turun temurun (Notoatmodjo, S, 2012). Pengetahuan baru secara perlahan dapat merubah tradisi masyarakat Kelurahan Rancanumpang dari sebelumnya buang air besar di sawah dan kebun, menjadi ke jamban.

\section{Kepercayaan}

Kepercayaan merupakan cerminan keyakinan individu yang berkembang di masyarakat. Hasil ini sejalan dengan pendapat Tratschin bahwa Kebudayaan dalam mempengaruhi sebuah praktek penggunaan jamban sehat terkait pula mengenai keyakinan pada tabu, gender, kepercayaan dan perbedaan setiap generasi dalam memahami kebudayaan. (Tratschin, 2011).

Perilaku merupakan perwujudan kesadaran budaya hidup sehat secara mandiri dan bermanfaat bagi pemeliharaan kesehatan. Hubungan antara manusia dan lingkungan merupakan suatu proses dalam perilaku (lihat gambar 2):

Gambar 2. Kebudayaan sebagai Penentu Perilaku Penggunaan Jamban

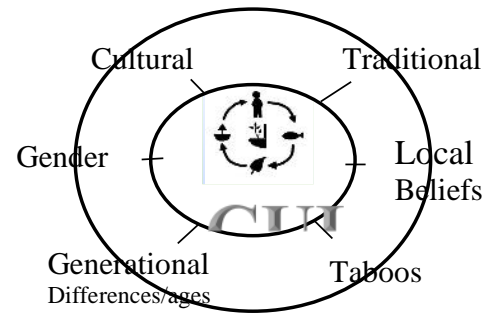

Sumber : Water, Sanitation and Culture. (Tratschin R., 2011)

Kebudayaan dalam mempengaruhi sebuah praktek penggunaan jamban terkait pula mengenai keyakinan pada tabu, gender, kepercayaan dan usia setiap generasi yang saling terkait dalam memahami kebudayaan (Tratschin, 2011).

Kepercayaan lebih mengarah kepada kepercayaan agama yang dianut oleh penduduk Kelurahan Rancanumpang. Ketaatan dan kepercayaan kepada agama mendorong penduduk untuk menggunakan jamban sehat. Kepercayaan merupakan salah satu ciri kebudayaan yang dibangun di tengah masyarakat. Kepercayaan merupakan landasan dalam melakukan perubahan perilaku di masyarakat agar pengetahuan yang diberikan dapat diterima dan dilaksanakan oleh masyarakat (Kiefer, 2007). Sistem kepercayaan dalam masyarakat dapat membangun suatu pengetahuan baru yang yang disepakati. Dalam pandangan terhadap jamban, terdapat persamaan kepercayaan responden bahwa jamban sehat merupakan cermin ketaatan kepada Tuhan. Cairan tubuh termasuk tinja merupakan bagian dari tubuh manusia dan memerlukan penanganan dalam menyelesaikannya dengan cara pembuatan jamban. 
Setiap individu memiliki berbagai macam kepercayaan terhadap suatu perilaku, namun ketika dihadapkan pada suatu kejadian tertentu, hanya sedikit dari keyakinan tersebut timbul untuk mempengaruhi perilaku. Keyakinan lebih menonjol dalam memengaruhi perilaku individu. Keyakinan yang menonjol ini dapat dibedakan menjadi :

1) Behavior belief yaitu keyakinan individu akan hasil suatu perilaku dan evaluasi atas hasil tersebut. Behavior belief akan mempengaruhi sikap terhadap perilaku (attitude toward behavior).

2) Normatif belief yaitu keyakinan individu terhadap harapan normatif orang lain yang menjadi rujukannya seperti keluarga, teman dan lingkungan. Harapan normatif ini membentuk variabel norma subjektif (subjective norm)

3) Control belief yaitu keyakinan individu tentang keberadaan hal-hal yang mendukung, menghambat perilaku dan persepsi tentang seberapa kuat hal-hal tersebut mempengaruhi perilakunya. Control belief membentuk variabel persepsi kontrol keperilakuan (perceived behavior control) (Ajzen 1991).

\section{Pengetahuan}

Pengetahuan merupakan hasil dari tahu yang dilakukan oleh indera terhadap objek tertentu. Pengetahuan lebih mengarah konsep-konsep etik dan emik dari penduduk dalam menggunakan jamban. Begitupun dengan sikap, bahwa setelah pengetahuan yang baik, penduduk terdorong untuk memiliki sikap positif terhadap penggunaan jamban. Perubahan untuk berperilaku sehat dapat dilakukan dengan mengurangi terhadap stigma budaya dengan diberikannya pemahaman mengenai pentingnya menggunakan jamban dengan meningkatkan pengetahuan masyarakat (Kaiser, 2011). Pentingnya menggunakan jamban dikaitkan dengan penyakit berbahaya sesuai dengan tahapan dan pemahaman masyarakat. Tahapan ilmu pengetahuan dan teknologi manusia dalam upaya kesehatan sebagai: (1) Mistik-religious, (2) Kedokteran, dan (3) Kesehatan. Tahapan ini terkait dengan konsepsi masyarakat tentang sehat-sakit, penyebab, pengobatan dan penyembuhannya, terus berkembang seiring dinamika sejarah kebudayaan dan peradaban (Loedin, 1982:10).

Penyelesaian masalah tersebut berdasarkan pengetahuan dari masyarakat baik dengan cara mencari sendiri maupun melalui agen-agen penggerak. Pengetahuan itu adalah salah satu simbol proses sosial sebagai hasil dari transmisi kepercayaan yang tertanam dalam pikiran orang yang percaya (Douglas, 1984:70). Dengan demikian, perlu mengembangkan suatu sistem pengetahuan dan teknologi berdasarkan sudut pandang masyarakat mengenai kesehatan (Permana, 2009).

Penggunaan jamban di Kelurahan Rancanumpang dapat berhasil karena pengaruh pengetahuan yang diterima masyarakat tentang pentingnya menggunakan jamban. Pengetahuan merupakan domain pertama dari pembentukan perilaku individu (Notoatmodjo, 2012). Pengetahuan yang didapat oleh masyarakat Kelurahan Rancanumpang sudah melewati tahapan pengetahuan yang terdiri dari tahu, memahami, mengaplikasikan, menganalisis, mensintesis dan mengevaluasi dari seluruh informasi yang diterima oleh masyarakat. Tahapan pengetahuan yang dilalui individu menjadikan dasar setiap individu secara bertahap mau dan mampu menggunakan jamban sesuai dengan proses-proses pengetahuan yang dipahami dan dilalui masyarakat.

Pengetahuan memperoleh hasil sigifikan dalam memengaruhi perilaku penggunaan jamban di Kelurahan Rancanumpang dan hal ini sesuai dengan peran pengetahuan sebagai domain kognitif yang bersinggungan dengan karakteristik masyarakat perkotaan yang memiliki perilaku berorientasi pada konsep pengandalan diri, 
kelembagaan, rasionalitas dan fungsi (Suparlan, 2004), sehingga masyarakat akan berkembang dengan pemikirannya setelah terintervensi oleh pengetahuan mengenai pentingnya menggunakan jamban.

\section{Sikap}

Sikap terbentuk setelah pengetahuan dimiliki oleh individu. Sikap merupakan reaksi atau respon yang masih tertutup dari seseorang terhadap suatu stimulus atau objek. Manifestasi sikap tidak dapat dilihat langsung tetapi hanya dapat ditafsirkan terlebih dahulu dari perilaku yang tertutup. Sikap secara nyata menunjukkan konotasi adanya kesesuaian reaksi terhadap stimulus tertentu yang dalam kehidupan sehari-hari merupakan reaksi yang bersifat emosional terhadap stimulus sosial (Notoatmodjo, 2012). Sikap terbentuk dengan menerima, menanggapi, menghargai dan bertanggung jawab. Perubahan perilaku masyarakat tidak dapat dilakukan dalam waktu yang singkat, perlu adanya kesinambungan dari faktor-faktor yang dapat memengaruhi terhadap perubahan perilaku. Tindakan manusia dipengaruhi oleh faktor-faktor internal yang mengarah kepada faktor predisposisinya dan faktor-faktor eksternal dari lingkungan, dilakukan secara wajar dan konsisten berdasarkan kemampuan relevan yang dapat dilakukan oleh individu (Ajzen, 2005:146).

Sikap masyarakat dalam penelitian ini merupakan salah satu faktor predisposisi yang memiliki angka signifikan. Sikap merupakan sebuah respon baik ketertarikan maupun ketidaktertarikan terhadap salah satunya kegiatan tertentu yang dipengaruhi oleh oleh aspek koginiti, afektif dan konatif dari individu-individu di masyarakat (Ajzen, 2005:4). Azwar (2009) menjelaskan bahwa sikap itu mempunyai 3 komponen pokok yang saling menunjang yang dapat memengaruhi terhadap perilaku individu. Komponen itu saling terkait dan harus ada dalam menghasilkan sikap yang sempurna. Komponen tersebut yaitu :

1. Komponen kognitif, merupakan representasi apa yang dipercayai oleh individu pemilik sikap, komponen ini berisi kepercayaan stereotipe yang dimiliki individu mengenai sesuatu dapat disamakan.

2. Komponen afektif merupakan perasaan yang menyangkut aspek emosional.

3. Komponen konatif merupakan aspek kecenderungan berperilaku tertentu sesuai dengan sikap yang dimiliki oleh seseorang dan berisi tendensi atau kecenderungan untuk bertindak/bereaksi terhadap sesuatu dengan cara-cara tertentu (Notoatmodjo, 2012).

Ketiga komponen ini secara bersama-sama membentuk sikap yang utuh telah terpenuhi oleh masyarakat Kelurahan Rancanumpang dalam perilaku menggunakan jamban. Sikap individu yang terbentuk sudah melalui tahapan-tahapan komponen pembentukan sikap sesuai dengan pengetahuan dan sikap dari masyarakat.

Jamban sehat merupakan salah satu pembangunan dalam rangka meningkatkan derajat kesehatan. Terbentuknya sikap individu dan masyarakat dalam berperilaku menggunakan jamban menunjukkan terbentuknya kerjasama diantara masyarakat dalam memenuhi akses jamban. Pelaksana pembangunan haruslah saling menghargai dengan kebutuhan masyarakat (Garna, 2002:104; de Sardan, 2005:24), sehingga perubahan perilaku masyarakat dalam menggunakan jamban di perkotaan baik milik pribadi ataupun kelompok tidak terlepas dari keterkaitan peran-peran tradisi dan modernisasi masyarakat perkotaan yang dipahami manfaatnya dan dapat dilakukan oleh masyarakat sesuai dengan karakteristik masyarakat perkotaan yang dinamis.

9. Pendidikan 
Dasar orang berperilaku dipengaruhi oleh nilai, sikap, pendidikan/pengetahuan. Proses berperilaku yang baik dimulai dari kesadaran, kemudian tertarik, selanjutnya akan melakukan uji coba, serta melakukan evaluasi, terakhir adalah mengadopsi substansi tersebut. Oleh karena itu perlu adanya promosi yang benar dan berkesinambungan agar masyarakat dapat memahami hidup bersih dan sehat dan mengaplikasikannya pada kehidupan sehari-hari. Masyarakat harus mengetahui akibatnya bila tidak menggunakan jamban sehat yaitu risiko terjangkit penyakit (Astuti, 2011).

Ketersediaan sarana jamban merupakan tanggung jawab seluruh lembaga pendidikan. Hal ini sejalan dengan penelitian Jasper (2012) bahwa akses terhadap air bersih dan jamban menjadi bagian fasilitas yang harus disediakan sekolah dan menjadi bagian dari prestasi sebuah lembaga pendidikan (Jasper, 2012).

Pentingnya pendidikan sebagai penggerak pemberdayaan sumber daya alam dan sumberd daya manusia merupakan konsep utama pendidikan lingkungan emansipatoris sebagai sebuah rencana aksi (Andrezza, 2016).

\section{Pekerjaan}

Pekerjaan salah satu cara agar mendapatkan biaya untuk membangun jamban keluarga. Jamban sehat memiliki dampak pada peningkatan kesehatan dan ekonomi rakyat karena berkurangnya beban keuangan negara akibat biaya pelayanan kesehatan sebagai dampak penyakit berbasis lingkungan (Minh, 2011).

\section{Perilaku stop buang air sembarangan}

Perilaku merupakan gabungan dari pengetahuan, sikap dan tindakan. Tindakan merupakan hasil dari pengetahuan dan sikap yang telah dimiliki oleh masyarakat dan telah dilaksanakan. Perilaku stop buang air besar sembarangan memiliki beberapa sub variabel berdasarkan ketentuan dalam Permenkes No. 3 tahun 2014. Tindakan penggunaan jamban sehat dipromosikan melalui refleksi tentang partisipasi, mobilisasi dan kontrol sosial merupakan tantangan dalam implantasi dan implementasi dari pendidikan sanitasi dasar. Inisiatif Partisipasi, Mobilisasi, Kontrol Sosial, Pendidikan Kesehatan dan Pendidikan Lingkungan diperlukan untuk pengembangan Kebijakan Sanitasi Dasar (Márcia Moisés, 2010). Keberhasilan penduduk Kelurahan Rancanumpang dalam menggunakan jamban berdasarkan peran-peran agen dalam hal ini Ketua RW, kader dan apparat dalam melakukan kompromi. Usulan dan mempromosikan solusi lebih baik yang mampu dilakukan oleh masyarakat. Tidak memaksakan solusi atau mencari alternatif yang menyulitkan masyarakat.

\section{Pandangan Masyarakat terhadap jamban ditinjau dari Faktor Predisposisi Bivariat}

Faktor predisposisi merupakan faktor yang berada dalam pikiran individu dan sangat dipengaruhi oleh kecenderungan untuk menerima atau menolak sesuatu berdasarkan pengalaman dan norma yang dimilikinya. Ketiga faktor tersebut yaitu Kepercayaan, Pengetahuan dan Sikap.

Masyarakat dalam memandang jamban tidak hanya sebagai sarana yang harus ada dan dipenuhi oleh setiap keluarga, tetapi ada makna tertentu terkait fungsi dan bahan buangan jamban berdasarkan faktor predisposisi masyarakat setempat. Faktor predisposisi dapat menilai perilaku berdasarkan pengalaman masa lalu yang memengaruhi cara-cara tindakannya di masa sekarang (Ajzen, 2005).

Terkait variabel penggunaan jamban di Kelurahan Rancanumpang yaitu sikap, norma subjektif dan persepsi kontrol masyarakat ditentukan melalui keyakinan-keyakinan utama. Determinan suatu perilaku merupakan hasil dari penilaian keyakinan-keyakinan dari individu, baik sebagai secara positif maupun negatif. Seperti dalam 
menentukan tindakan memindahkan septiktank mendekati sumber air, individu sudah memikirkan sesuai dengan pengetahuan dan lingkungan sekitarnya dengan harapan bahwa tindakan tersebut bermanfaat dan dapat dipertanggungjawabkan Pengetahuan ditingkatkan melalui pembinaan terus menerus pada masyarakat dan memberikan pemahaman terkait informasi terbaru berperilaku sanitasi.

Hasil penelitian menunjukkan bahwa secara simultan faktor predisposisi berpengaruh kepada perilaku penggunaan jamban sehat. Menurut Wasserman dan Faust (1994) yang menyebutkan bahwa perilaku manusia melekat pada hubungan antarpersonal dalam jaringan kerja, yang bentuknya bisa formal dan informal. Putnam (2000) menegaskan bahwa semakin kuat ikatan sosial yang dimiliki oleh suatu masyarakat, maka mereka semakin berpeluang untuk menggerakkan sumber daya, baik lokal maupun ekstra lokal. Landeers (2002) berpendapat bahwa pilihan akhir dari seseorang adalah gambaran dari atribut di dirinya dan sekaligus pengaruh dari orang-orang sekitarnya (Joga, 2017). Hal ini tergambar dari penyediaan akses jamban secara mandiri oleh masyarakat RW 01 dan 02. Secara simultan setiap penduduk berusaha memenuhi akses jamban secara mandiri. 13. Pandangan Masyarakat terhadap jamban ditinjau dari Faktor Predisposisi Multivariat

Dalam menguji pengaruh faktor-faktor predisposisi terkait penggunaan jamban sehat responden Kelurahan Rancanumpang, semua faktor predisposisi di diuji dan digabungkan untuk melaihat pengaruhnya. Faktor predisposisi yang dilakukan bersama-sama berpengaruh kepada perilaku responden dalam menggunakan jamban sehat.

Keberhasilan penduduk dalam pemenuhan akses jamban meningkat dari tahun ke tahun. Dikaitkan dengan status kesehatan, jamban bukan merupakan pengaruh langsung yang dapat menyebabkan kesakitan dan kematian pada anak namun jamban sehat dan air bersih merupakan faktor prediktor.

Faktor predisposisi merupakan faktor yang berada dalam pikiran individu dan sangat dipengaruhi oleh kecenderungan untuk menerima atau menolak sesuatu berdasarkan pengalaman dan norma yang dimilikinya. Keseluruhan terkait faktor predisposisi bila dilakukan bersama-sama memengaruhi secara simultan kepada perilaku penggunaan jamban masyarakat di Kelurahan Rancanumpang. Namun demikian, bila dilakukan secara parsial, maka hanya 3 faktor predisposisi yang berpengaruh kepada perilaku penggunaan jamban sehat. Ketiga faktor tersebut yaitu Kepercayaan, Pengetahuan dan Sikap.

Kepercayaan lebih mengarah kepada kepercayaan agama yang dianut oleh penduduk Kelurahan Rancanumpang. Ketaatan dan kepercayaan kepada agama mendorong penduduk untuk menggunakan jamban sehat. Kepercayaan merupakan salah satu ciri kebudayaan yang dibangun di tengah masyarakat. Kepercayaan merupakan landasan dalam melakukan perubahan perilaku di masyarakat agar pengetahuan yang diberikan dapat diterima dan dilaksanakan oleh masyarakat (Kiefer, 2007). Sistem kepercayaan dalam masyarakat dapat membangun suatu pengetahuan baru yang yang disepakati. Dalam pandangan terhadap jamban, terdapat persamaan kepercayaan responden bahwa jamban sehat merupakan cermin ketaatan kepada Tuhan. Cairan tubuh termasuk tinja merupakan bagian dari tubuh manusia dan memerlukan penanganan dalam menyelesaikannya dengan cara pembuatan jamban. Penyelesaian masalah tersebut berdasarkan pengetahuan dari masyarakat baik dengan cara mencari sendiri maupun melalui agen-agen penggerak. Pengetahuan itu adalah salah satu simbol proses sosial sebagai hasil dari transmisi kepercayaan yang tertanam dalam pikiran orang yang percaya (Douglas, 1984). 
Setiap individu memiliki berbagai macam keyakinan terhadap suatu perilaku, namun ketika dihadapkan pada suatu kejadian tertentu, hanya sedikit dari keyakinan tersebut timbul untuk mempengaruhi perilaku. Keyakinan lebih menonjol dalam memengaruhi perilaku individu. Keyakinan yang menonjol ini dapat dibedakan menjadi :

1) Behavior belief yaitu keyakinan individu akan hasil suatu perilaku dan evaluasi atas hasil tersebut. Behavior belief akan mempengaruhi sikap terhadap perilaku (attitude toward behavior).

2) Normatif belief yaitu keyakinan individu terhadap harapan normatif orang lain yang menjadi rujukannya seperti keluarga, teman dan lingkungan. Harapan normatif ini membentuk variabel norma subjektif (subjective norm)

3) Control belief yaitu keyakinan individu tentang keberadaan hal-hal yang mendukung atau menghambat perilakunya dan persepsinya tentang seberapa kuat hal-hal tersebut mempengaruhi perilakunya. Control belief membentuk variabel persepsi kontrol keperilakuan (perceived behavior control) (Ajzen 1991).

Terkait dengan penggunaan jamban sehat di Kelurahan Rancanumpang sikap, norma subjektif dan persepsi kontrol masyarakat ditentukan melalui keyakinan-keyakinan utama. Determinan suatu perilaku merupakan hasil dari penilaian keyakinan-keyakinan dari individu, baik sebagai secara positif maupun negatif. Seperti dalam menentukan tindakan memindahkan septiktank mendekati sumber air, individu sudah memikirkan sesuai dengan pengetahuan dan lingkungan sekitarnya dengan harapan bahwa tindakan tersebut bermanfaat dan dapat dipertanggungjawabkan.

Pengetahuan lebih mengarah konsep-konsep etik dan emik dari penduduk terkait penggunaan jamban sehat. Begitupun dengan sikap, bahwa setelah pengetahuan yang baik, penduduk terdorong untuk memiliki sikap positif terhadap penggunaan jamban sehat. Perubahan untuk berperilaku sehat dapat dilakukan dengan mengurangi terhadap stigma budaya dengan diberikannya pemahaman mengenai pentingnya jamban sehat dengan meningkatkan pengetahuan masyarakat (Kaiser, 2011). Pentingnya jamban sehat dikaitkan dengan penyakit berbahaya sesuai dengan tahapan dan pemahaman masyarakat. Tahapan ilmu pengetahuan dan teknologi manusia dalam upaya kesehatan sebagai: (1) Mistik-religious, (2) Kedokteran, dan (3) Kesehatan. Tahapan ini terkait dengan konsepsi masyarakat tentang sehat-sakit, penyebab, pengobatan dan penyembuhannya, terus berkembang seiring dinamika sejarah kebudayaan dan peradaban (Loedin, 1982).

Sikap masyarakat dalam penelitian ini merupakan salah satu faktor predisposisi yang memiliki angka signifikan. Sikap merupakan sebuah respon baik ketertarikan maupun ketidaktertarikan terhadap salah satunya kegiatan tertentu yang dipengaruhi oleh oleh aspek kognitif, afektif dan konatif dari individu-individu di masyarakat (Ajzen, 2005).

Tindakan penggunaan jamban sehat dipromosikan melalui refleksi tentang partisipasi, mobilisasi dan kontrol sosial merupakan tantangan dalam implantasi dan implementasi dari pendidikan sanitasi dasar. Inisiatif Partisipasi, Mobilisasi, Kontrol Sosial, Pendidikan Kesehatan dan Pendidikan Lingkungan diperlukan untuk pengembangan Kebijakan Sanitasi Dasar (Márcia Moisés, 2010).

Dengan demikian, perlu mengembangkan suatu sistem pengetahuan dan teknologi berdasarkan sudut pandang masyarakat mengenai kesehatan (Permana, 2009). Masyarakat perkotaan dengan karakteristiknya, memilki potensi membangun kemandiriannya dalam menciptakan jamban sehat dari dan untuk masyarakat. 
Masyarakat sebagai pengguna dan menentukan keberlanjutan sarana yang dipakai. Pengetahuan baru mengenai jamban sehat diperlukan masyarakat sebagai bagian dari perubahan perilaku yang terakumulasi dari mulai pemahaman jamban sehat di keluarga berkembang menjadi pengetahuan dan dipraktekan dari oleh dan untuk masyarakat. Sampai dengan penelitian selesai dilaksanakan, pengetahuan dan sikap masyarakat telah memahami tentang kriteria dan pentingnya jamban sehat dalam pemeliharaan kesehatan. Responden yang mengetahui bahwa jarak septiktank dan sumber air kurang dari 10-11 meter, akan mengganti sarananya. Sampai dengan penelitian selesai, tindakan belum dilakukan masyarakat mengingat perbaikan sarana memerlukan biaya dan butuh waktu dalam mengumpulkannya.

Faktor predisposisi yang memberikan pengaruh positif lainnya yaitu gender, tabu, nilai-nilai dan pekerjaan. Hasil ini sejalan dengan pendapat Tratschin bahwa Kebudayaan dalam mempengaruhi sebuah praktek penggunaan jamban sehat terkait pula mengenai keyakinan pada tabu, gender, kepercayaan dan perbedaan setiap generasi dalam memahami kebudayaan. (Tratschin, 2011). Proses dan indikator budaya dari masyarakat yang dapat dijelaskan melalui nilai-nilai budaya setempat (Pizzirani, 2014). Faktor-faktor budaya yang diakomodir pada penggunaan jamban sehat di masyarakat akan meningkatkan keberlanjutan penggunaan jamban sehat.

Jamban dikaitkan dengan gender terutama wanita yang menyatakan bahwa jamban sehat berpengaruh pada aspek psikososial wanita (Hulland, 2015). Responden di Kelurahan Rancanumpang sebesar $70.88 \%$ adalah wanita dan sebesar $48.76 \%$ sebagai ibu rumah tangga. Peran wanita dalam mengajak masyarakat berperilaku menggunakan jamban sehat sangat besar terutama di 2 RW yang bukan komplek.

Perilaku penggunaan jamban di Kelurahan Rancanumpang sebagai masyarakat perkotaan masih memaknai tabu terkait jamban. Jamban dikatakan tempat kotor dapat berbeda makna. Makna "kotor" berarti suatu masalah yang keluar dari suatu tempat, makna "polusi dan tabu" merupakan batasan berbeda dan aturan sosial termasuk batas-batas nilai-nilai dalam lingkungannya yang dimiliki oleh setiap budaya (Jewit, 2011). Masyarakat berpendapat kotor karena jamban merupakan tempat pembuangan dan bahan buangan dapat dianggap benda "kotor" sehingga sebaiknya diluar rumah atau dibagian luar rumah dekat dengan air mengalir. Namun ada pula masyarakat yang memaknai jamban adalah tempat bersih karena jamban yang dimiliki dalam kondisi bersih dan selalu dibersihkan.

Dasar orang berperilaku dipengaruhi oleh nilai, sikap, pendidikan/pengetahuan. Proses berperilaku yang baik dimulai dari kesadaran, kemudian tertarik, selanjutnya akan melakukan uji coba, serta melakukan evaluasi, terakhir adalah mengadopsi substansi tersebut. Oleh karena itu perlu adanya promosi yang benar dan berkesinambungan agar masyarakat dapat memahami hidup bersih dan sehat dan mengaplikasikannya pada kehidupan sehari-hari. Masyarakat harus mengetahui akibatnya bila tidak menggunakan jamban sehat yaitu risiko terjangkit penyakit (Astuti, 2011:388). Perubahan perilaku masyarakat tidak dapat dilakukan dalam waktu yang singkat, perlu adanya kesinambungan dari faktor-faktor yang dapat memengaruhi terhadap perubahan perilaku. Tindakan manusia dipengaruhi oleh faktor-faktor internal yang mengarah kepada faktor predisposisinya dan faktor-faktor eksternal dari lingkungan, dilakukan secara wajar dan konsisten berdasarkan kemampuan relevan yang dapat dilakukan oleh individu (Ajzen, 2005:146). 


\section{Kesimpulan}

Berdasarkan kajian dan pembahasan dari hasil penelitian, maka faktor-faktor dominan yang memengaruhi perilaku akses jamban sehat :

1. Faktor-faktor dominan yang memengaruhi perilaku penggunaan jamban ditinjau dari faktor predisposisi adalah kepercayaan, pengetahuan dan sikap masyarakat terhadap penggunaan jamban sehat. Sedangkan faktor predisposisi lainnya bila dilakukan bersama-sama maka memengaruhi masyarakat dalam berperilaku menggunakan jamban sehat.

2. Secara simultan, faktor predisposisi berpengaruh kepada perilaku, namun demikian faktor penguat dan faktor pemungkin mendorong faktor predisposisi dalam keberlanjutan Open Defecation Free.

3. Keberhasilan penggunaan jamban di Kelurahan Rancanumpang adalah penduduk antusias dalam menerima perbaikan bagi lingkungannya melalui pemicuan dan sudah memiliki potensi kesadaran dengan keteraturan daerahnya dalam memenuhi fasilitas jamban bagi keluarganya. Tokoh masyarakat aktif berperan dalam mengelola masyarakat untuk mau berubah. Peran Lurah dalam mendorong warga dibantu kader aktif dan pengurus dalam memenuhi akses jamban bagi masyarakat terutama masyarakat kurang mampu.

4. Sebagai langkah kemandirian berperilaku menggunakan jamban sehat, diperlukan pemahaman mengenai pemberdayaan mulai sejak dalam keluarga. Keluarga merupakan bagian dari fungsi kekerabatan dan kekerabatan merupakan relasi sosial yang sangat berperan pada cara hidup individu di masyarakat. Kerjasama dalam keluarga dan masyarakat menjadi kunci penting keberhasilan penggunaan jamban di Kelurahan Rancanumpang.

\section{DAFTAR PUSTAKA}

Ajzen, I. (2005). Attitudes, Personality and Behavior. England : Open University Press.

Astuti, W. (2011). Perilaku Hidup Bersih dan Sehat (PHBS) dalamRumah Tangga Ibu Hamil dan Ibu Pernah Hamil di Indonesia. Buletin Penelitian Sistem Kesehatan, 14(Kesehatan dan Perilaku), 382-390.

De Sardan, J.P.O. (2005). Anthropology and Development. UK: Zed Book Ltd.

Douglas, M. (2001). Purity and Danger. New York: Routledge

Foster, G. M., \& Anderson, B. G. (2006). Antropologi Kesehatan. (M. F. Priyanti Pakan Suryadarma, Trans.) Jakarta: UI Press.

Garna, J. K. (2002). Teori-teori Perubahan Sosial. Bandung: Primaco Akademika.

IUWASH, I. U. (2015). Meningkankan Gaya Hidup dan Kesehatan: Sebuah Panduan Promosi Sanitasi Perkotaan . Jakarta: Bappenas.

Jewwit, S. (2011). Geographies of shit: Spatial and temporal variations in attitudes towards human waste. Sagepub, 35(5) 608-626, 608.

Joga, N. 2017. Mewariskan Kota Layak Huni. Jakarta : PT Gramedia Pustaka Utama 
Kaiser, S. (2011). Water, Sanitation and Culture, Swiss: seecon international gmbh.

Kiefer, C. W. (2007). Doing Health Anthropology. New York: Springer Publishing Company.

Lapau, B., Saiffudin, A.F. (2015). Epidemiologi dan Antropologi. Jakarta: Prenadamedia Grup.

Loedin, A.A. (1982). Peranan Ilmu-Ilmu Sosial dan Pengembangan Kesehatan. Jakarta: Departemen Kesehatan RI.

Marzali, A. (2007). Antropologi dan Pembangunan Indonesia. Jakarta: Kencana Prenada Media Group.

Notoatmodjo, S. (2012). Promosi Kesehatan dan Ilmu Perilaku. Jakarta: Rineka Cipta.

Permana, R. C. (2009, April). Masyarakat Baduy dan Pengobatan Tradisional Berbasis Tanaman. Wacana, 11 No 1, 81-94.

Singer, M. (2015). Anthropology of Infectious Disease. USA: Left Coast Press Inc.

Suparlan, P. (2004). Masyarakat dan Kebudayaan Perkotaan. Jakarta: Yayasan Pengembangan Kajian Ilmu Kepolisian.

Soeparman., S. (2002). Pembuangan Tinja \& Limbah Cair (Suatu Pengantar). Jakarta: Penerbit Buku Kedokteran EGC

Tratschin, R. (2011). Water, Sanitation and Culture, Swiss: seecon international gmbh.

UNICEF Indonesia. (2012). Air Bersih, Sanitasi dan Kebersihan, Jakarta: UNICEF.

United States Agency for International Development (USAID). (2016). Urban Sanitation, Amerika: USAID.

Van Klinken, G., Berenschot, W. (2014). In search in Middle Indonesia :kelas menengah di kota-kota menengah. Jakarta: Yayasan Pustaka Obor Jakarta.

Van Vliet, B., Spaargaren, G., Oosterveer, P. (2010). Social Perspective on the Sanitation Challenge. Dordrecht: Springer.

Water and Sanitation Program (WSP). (2015). Water Supply and Sanitation in Indoneisa. Turning Finance into Service for the Future. 1st ed. Jakarta: WSP.

WSP, W. S. (2015). Water Supply and Sanitation in Indoneisa. Turning Finance into Service for the Future (1st ed.). Jakarta: WSP. 